\title{
Corrosion Behaviour of High-Mn TWIP Steels with Electroless Ni-P Coating
}

\author{
A.S. Hamada and L.P. Karjalainen* \\ Department of Mechanical Engineering, University of Oulu, P.O. Box 4200, 90014 Oulu, Finland
}

\begin{abstract}
An attempt has been taken to improve the corrosion resistance of twinning-induced plasticity (TWIP) steels (Fe-25Mn and Fe-25Mn-3Al) by electroless Ni-P coating. Corrosion resistance in $3.5 \% \mathrm{NaCl}$ and $0.1 \mathrm{M} \mathrm{H}_{2} \mathrm{SO}_{4}$ solutions was characterized by the potentiodynamic polarization curves and Tafel method calculations. It was found that Ni-P coating improved the corrosion resistance by the factor of 4 and 40 in $3.5 \% \mathrm{NaCl}$ and $0.1 \mathrm{M} \mathrm{H}_{2} \mathrm{SO}_{4}$, respectively. Post-heat treatments, commonly used to increase hardness and wear resistance of Ni-P deposits, were found to reduce the corrosion resistance, even though the $1 \mathrm{~h}$ annealing at $700^{\circ} \mathrm{C}$ less than at $350^{\circ} \mathrm{C}$. Also, the adhesion of the coating on the steels was impaired in annealing. The lowered corrosion resistance in annealing can be suggested to result from the crystallization of the amorphous coating and the formation of $\mathrm{Ni}_{3} \mathrm{P}$ particles, but at $700^{\circ} \mathrm{C}$, the formation $\mathrm{MnO}$ layer on the top of the coating promoted the resistance by enhancing the passivation in the $3.5 \% \mathrm{NaCl}$ solution.
\end{abstract}

Keywords: High-Mn TWIP steels, electroless Ni-P coating, corrosion resistance, post-heat treatment.

\section{INTRODUCTION}

High-Mn austenitic steels are subject of a considerable interest, for they have some unique properties owing to transformation-induced plasticity (TRIP) or particularly twinning-induced plasticity (TWIP) effects [1,2]. The TWIP effect means intense formation of mechanical twins during straining and these twins result in enhanced strain hardening that, in turn, provides a high tensile strength and excellent ductility for the steel. For efficient TWIP effect and to prevent martensite formation in straining, the stacking fault energy (SFE) of the steel must be in the proper range, not too high, not too low, as discussed in several papers, e.g. $[3,4]$. For automotive applications high-Mn TWIP steels are attractive due to their very high energy absorption, which is more than two times of that of conventional high strength steels, and high stiffness that improves the crash safety $[3,4]$.

Manganese is considered as the main alloying element in TWIP-steels, where it is crucial to preserve the austenitic structure [5], and also for controlling the SFE [6]. However, a high concentration of $\mathrm{Mn}$ makes such steels electrochemically reactive in chloride and acidic solutions due to its high dissolution rate [7,8]. Good corrosion resistance of automotive steels is one of the strict demands of car manufacturers besides the legal requirements. Two approaches can be used to enhance the corrosion resistance of high-Mn TWIP steels. The first is the alloying with Al or $\mathrm{Al} / \mathrm{Cr}$. Even though $\mathrm{Al}$ and $\mathrm{Cr}$ additions increase the corrosion resistance of these steels, they have detrimental influence on the mechanical properties through increased SFE $[9,10]$. The second approach is to modify the surface by plating, chemical conversion coating, thermal spraying, etc. Electroless nickel coatings are widely utilized for corrosion

*Address correspondence to this author at the Department of Mechanical Engineering, University of Oulu, P.O. Box 4200, 90014 Oulu, Finland; Tel: +358 8553 2140; Fax: +358 8553 2165; E-mail: karjalainen@oulu.fi protection in severe environments [11,12], and it can be expected that these coatings might improve the corrosion resistance of TWIP steels as well. Further, a post-heat treatment is used for improving hardness, wear resistance and adhesion of electroless Ni plating on steels [13]. In the present work, electroless Ni-P coatings were deposited on two TWIP steels and two post-heat treatments used to test their corrosion resistance in chlorine and acidic environments.

\section{EXPERIMENTAL}

Two high-Mn TWIP steels with the basic compositions Fe-26Mn-0.14C and Fe-24Mn-3Al-0.10C (elements in wt$\%$ ) were used in the present study. The melting procedure and hot rolling of the investigated steels have been described elsewhere in detail [14]. Circular specimens with $15 \mathrm{~mm}$ in diameter were ground, polished and cleaned in hot diluted $\mathrm{NaOH}$. An acidic hypophosphite-reduced nickel bath was chosen as the plating bath. Nickel sulphate hexahydrate was used as the source of nickel, while sodium hypophosphite served as the reducing agent and source of phosphorus. Besides them, the bath also contained suitable amounts of complexing agents and stabilizers. The bath was operated at the $\mathrm{pH}$ range of 5-5.5 and at the temperature of $90 \pm 2{ }^{\circ} \mathrm{C}$ for the $1 \mathrm{~h}$ plating duration. Annealing treatments of the asplated Ni-P coatings were performed at $350^{\circ} \mathrm{C}$ and $700^{\circ} \mathrm{C}$ for $1 \mathrm{~h}$ under an Ar atmosphere. The structure of the deposits was characterized using the X-ray diffraction with $\mathrm{Cu}-\mathrm{K}_{\alpha}$ radiation and a scanning electron microscope (SEM) with an EDX unit. Additionally the glow discharge optical emission spectroscopy (GD-OES: JY5000) was used to obtain the elemental depth distribution profiles.

The adhesion of coatings was measured by applying the Peel test, in which a $0.05 \mu \mathrm{m}$ thick cyanoacrylate adhesive was used between the specimen and a silane. The ductility of the coating was estimated using bending tests around a conical head. The bending angle corresponding to certain 
strain at the surface, at which cracks appeared on the coating, was considered as a measure of ductility. The electrical conductivities of the Ni coatings were measured using a direct current transistor (Model TX 2000) equipped with nano-voltmeter. Ribbons of the $\mathrm{Ni}$ coatings were used in such measurements after careful cutting the specimens. All measurements were carried out at $20^{\circ} \mathrm{C}$.

The corrosion behaviour of TWIP steels and deposits coated with electroless $\mathrm{Ni}-\mathrm{P}$ was evaluated using anodic potentiodynamic polarization in aerated $3.5 \% \mathrm{NaCl}$ solution and $0.1 \mathrm{M} \mathrm{H}_{2} \mathrm{SO}_{4}$. A conventional three-compartment glass cell with a graphite bar as a counter electrode and a saturated calomel electrode (SCE) as the reference electrode was employed for the electrochemical measurements. Samples were immersed in the solution for $1 \mathrm{~h}$ at the open circuit preceding polarization. The polarization was initiated at about $250 \mathrm{mV}$ negative to the corrosion potential $\left(E_{\text {corr }}\right)$ followed by scanning towards the noble direction at a rate of $1 \mathrm{mVs}^{-1}$.

\section{RESULTS AND DISCUSSION}

\subsection{Characteristics of Coatings}

Since the electroless Ni-P plating is a chemical reduction process, the coatings had a uniform thickness of about 20 $\mu \mathrm{m}$. The XRD patterns of the as-deposited Ni-P coatings on the $\mathrm{Fe}-25 \mathrm{Mn}$ steel and those after the annealing treatments at $350^{\circ} \mathrm{C}$ and $700^{\circ} \mathrm{C}$ for $1 \mathrm{~h}$ are shown in Fig. (1). It can be seen that the as-deposited Ni-P coating shows a single broad, diffuse peak, which is the indication of an amorphous structure. The peak broadening is attributable mainly to the supersaturated amorphous phase with phosphorus, rather than compressive microstresses $[15,16]$. The post-heat treatments at $350{ }^{\circ} \mathrm{C}$ and $700^{\circ} \mathrm{C} h$ resulted in the crystallization of the fcc-nickel and precipitation of the bct$\mathrm{Ni}_{3} \mathrm{P}$ phase. However, at $700^{\circ} \mathrm{C}$, two additional peaks of very low intensity are observed at around $40^{\circ}$ and $58.7^{\circ}$. These peaks correspond to the reflections from the (200) and (220) planes of $\mathrm{MnO}$, defined to exist at 40.558 and 58.728 degrees, respectively, by the Joint Committee on Powder Diffraction Standards (JCPDS card \#7-230). It can be noticed that the amount of $\mathrm{Ni}_{3} \mathrm{P}$ phase has increased at $700^{\circ} \mathrm{C}$, where the intensities of $\mathrm{Ni}_{3} \mathrm{P}$ peaks are higher than those of Ni peaks.

Mechanical properties of the Ni-P coatings were influenced by the heat treatment, as shown in Table 1 . The annealing at $350^{\circ} \mathrm{C}$ for $1 \mathrm{~h}$ increased the hardness from 643 to $760 \mathrm{HV}_{100}$. Ductility (i.e., the elongation, see Table 1) was slightly decreased by the annealing treatment, too. The increase in hardness and decrease in ductility can be attributed to the precipitation of fine $\mathrm{Ni}$ crystallites and the $\mathrm{Ni}_{3} \mathrm{P}$ particles during the phase transition, as shown in XRD patterns in Fig. (1). The hardening effect of the fine $\mathrm{Ni}_{3} \mathrm{P}$ particles is assumed to result from their high strength and high shear modulus [16]. On annealing at $700^{\circ} \mathrm{C}$ for $1 \mathrm{~h}$, the hardness increased up to $950 \mathrm{HV}_{100}$, obviously as a result of the larger number of $\mathrm{Ni}_{3} \mathrm{P}$ particles, as can be concluded from the XRD pattern in Fig. (1).

Even though the hardness increased with the post-heat treatments, the adhesion strength was observed to decrease, as evident from the results in Table 1. This decrease in the adhesion may be due to several factors. Firstly, with increasing temperature, the different thermal expansion coefficients between the Ni film and the steel substrate cause volumetric shrinkage in the deposit. Secondly, crystallization accompanied by the reduction of the boundary surface area of $\mathrm{Ni}$ grains lowers the cohesive property of the Ni plating. Both factors may cause local peeling and partial destruction of the coating in the Peel test. Tsai et al. [17] correlated the decrease in the adhesion of electroless $\mathrm{Ni}$ plating to the precipitation of $\mathrm{Ni}_{3} \mathrm{P}$ particles in the course of annealing.

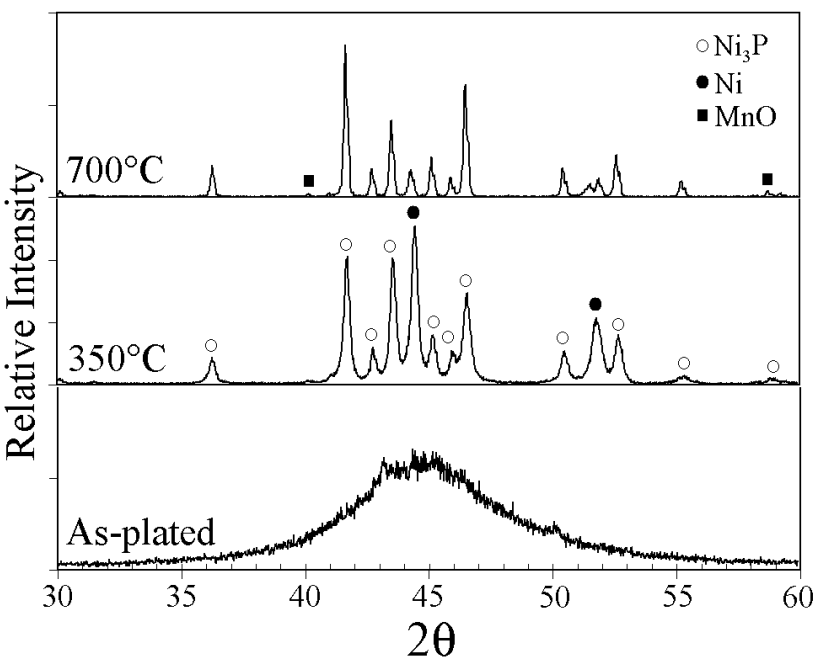

Fig. (1). X-ray diffraction patterns of Ni-P deposits on the Fe-25Mn steel, as-plated and after post-heat treatments for $1 \mathrm{~h}$ at $350^{\circ} \mathrm{C}$ and $700^{\circ} \mathrm{C}$.

The increase of the electrical conductivity on annealing, as observed in Table $\mathbf{1}$, is presumably a result from the removal of solid solution elements from the Ni matrix by the formation of $\mathrm{Ni}_{3} \mathrm{P}$ precipitates. Hence, it seems that the residual solute content of $\mathrm{P}$ in the coating after annealing at $700^{\circ} \mathrm{C}$ is lower than its concentration in the other instances.

Table 1. Mechanical and Physical Properties of Electroless Ni-P Coating on the Fe-25Mn Steel

\begin{tabular}{|c|c|c|c|}
\hline Property & As-Plated & $\begin{array}{c}\text { Treated } \\
\mathbf{a t ~} 350^{\circ} \mathbf{C}\end{array}$ & $\begin{array}{c}\text { Treated } \\
\text { at } \mathbf{7 0 0}^{\circ} \mathbf{C}\end{array}$ \\
\hline \hline Structure & Amorphous & Crystalline & Crystalline \\
\hline Hardness, $\mathrm{HV}_{100}$ & 643 & 760 & 950 \\
\hline Adhesion, $\mathrm{kg} / \mathrm{cm}^{2}$ & $820-3700$ & $850-3000$ & $370-2000$ \\
\hline Elongation, $\%$ & $3 \pm 2$ & ---- & $2 \pm 2$ \\
\hline Resistivity, $\mu \Omega / \mathrm{cm}$ & 38 & 22 & 13 \\
\hline
\end{tabular}

Fig. (2) exhibits the GD-OES depth profiles for the Ni-P deposits, as-plated and after annealing for $1 \mathrm{~h}$ at $350^{\circ} \mathrm{C}$ and $700^{\circ} \mathrm{C}$. As seen from Fig. (2a), the distribution of $\mathrm{Ni}$ and $\mathrm{P}$ elements is not totally uniform across the as-plated $\mathrm{Ni}-\mathrm{P}$ layer on the Fe-25Mn-3Al steel. The distributions of $\mathrm{Co}, \mathrm{Ni}$, $\mathrm{P}, \mathrm{Mn}, \mathrm{Al}$ and Fe remained unchanged during the annealing at $350^{\circ} \mathrm{C}$, as evident from Fig. (2b). However, in annealing at $700^{\circ} \mathrm{C}$ these distributions changed, as seen in Fig. (2c, d), evidently due to faster diffusion. Other two features can be 

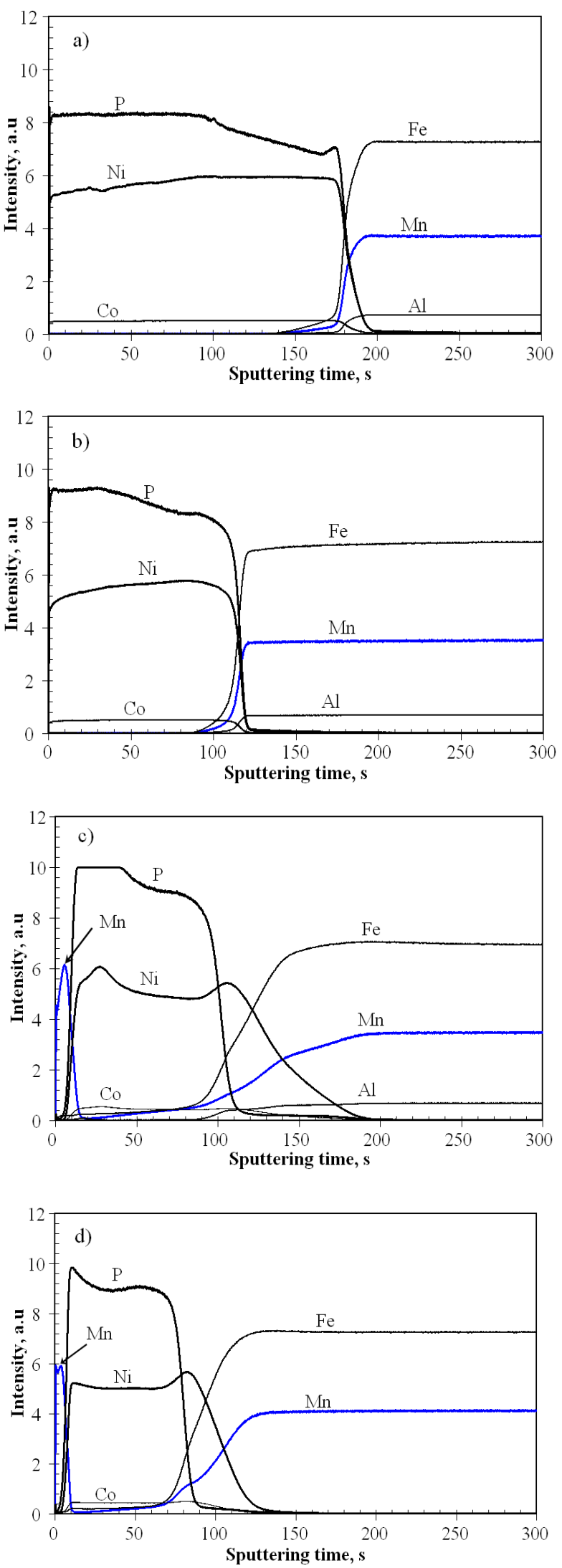

Fig. (2). GD-OES depth distribution profiles of $\mathrm{Co}, \mathrm{Ni}, \mathrm{P}, \mathrm{Mn}, \mathrm{Al}$ and $\mathrm{Fe}$ for Ni-P deposits with different annealing temperatures: from (a) to (c) on Fe-25Mn-3Al and (d) on Fe-25Mn: (a) as-plated, (b) $350^{\circ} \mathrm{C} / 1 \mathrm{~h},(\mathbf{c})$ and (d) $700^{\circ} \mathrm{C} / 1 \mathrm{~h}$. seen in the last figures. Mn atoms accumulate on the surface of the deposit and form a MnO layer on the top. This must be a result from a high diffusivity of $\mathrm{Mn}$ in fcc-Ni [18]. Secondly, Ni atoms diffuse deeper into the Al-bearing steel than into the Al-free steel, the depths being 11 and $5 \mu \mathrm{m}$, respectively. It has been reported that the addition of Al into the Fe-Mn system leads to a lattice expansion of the austenite matrix due to the larger atomic radius of Al [19]. Consequently, the diffusion rate of $\mathrm{Ni}$ atoms increases. However, no diffusion of $\mathrm{P}$ was detected into the steels even in the course of $1 \mathrm{~h}$ annealing at $700^{\circ} \mathrm{C}$. This must be a consequence of a very low diffusivity of $\mathrm{P}$ in the austenite.

Based on the GD-OES analysis of the and SEM-EDX analysis at high magnifications of the of the EN-P coating on Fe-25Mn-3Al steel, a schematic drawing of the deposits in two conditions is shown in Fig. (3).

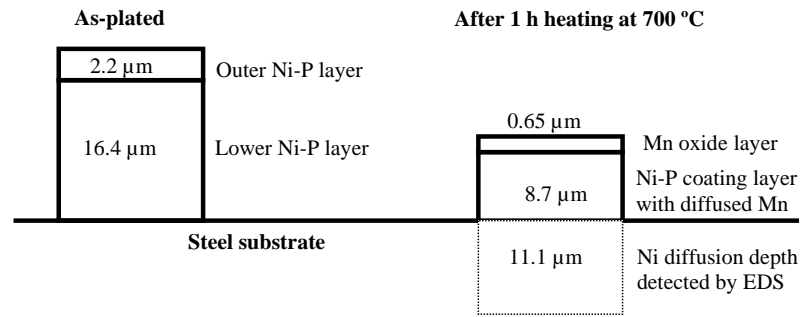

Fig. (3). Schematic drawing of the deposited electroless Ni-P layers on Fe-25Mn-3Al TWIP steel with annealing at $700^{\circ} \mathrm{C}$ for $1 \mathrm{~h}$, based on GD-OES and SEM-EDX analyses.

The main interest of $\mathrm{MnO}$ layer is a classic example of an antiferromagnetic compound. Thus its presence as an additional layer will not change the magnetic properties of high-Mn TWIP steels.

The electrochemical reactions are surface reactions, and therefore the surface layer of Ni-P deposits after the heat treatments was also characterized by SEM-EDX. These examinations revealed that the surface of the Ni-P coating annealed at $350^{\circ} \mathrm{C}$ contains coarse particles of $\mathrm{Ni}_{3} \mathrm{P}$, which can act as cathodic regions on the coating. However, at $700^{\circ} \mathrm{C}$, a thin $\mathrm{MnO}$ layer with $0.60 \mu \mathrm{m}$ in thickness was formed on the surface, the fact that was also confirmed by the Mn distribution in Fig. (2c, d). The cross-section of the $\mathrm{Ni}-\mathrm{P}$ coating, annealed at $700^{\circ} \mathrm{C}$, shows the formation of small particles containing $\mathrm{Mn}, \mathrm{Ni}$ and $\mathrm{P}$, in consistence with the results reported in Ref. [20].

\subsection{Corrosion Resistance}

The polarization curves obtained for the electroless Ni-P coated steels as well as steels without coating, in $3.5 \% \mathrm{NaCl}$ solution and $0.1 \mathrm{M} \mathrm{H}_{2} \mathrm{SO}_{4}$, are shown in Fig. (4). The corrosion potential $\left(\mathrm{E}_{\text {corr }}\right)$ and corrosion current density $\left(\mathrm{I}_{\text {corr }}\right)$ calculated using the Tafel extrapolation method are given in Table 2. Only the steel $\mathrm{Fe}-25 \mathrm{Mn}$ was tested in the $\mathrm{NaCl}$ solution and the steel $\mathrm{Fe}-25 \mathrm{Mn}-3 \mathrm{Al}$ in the $\mathrm{H}_{2} \mathrm{SO}_{4}$ solution. However, from the elemental distributions in Fig. (2c, d), it can be noticed that the chemical compositions of the surface layer are similar in the both steels, for $\mathrm{Al}$ is present only in the interface of the coating and the steel even after the annealing treatment. Only $\mathrm{Mn}$ is enriched to the surface layer from the steel. Therefore, similar corrosion behavior of the coatings can be expected for the both steels. 

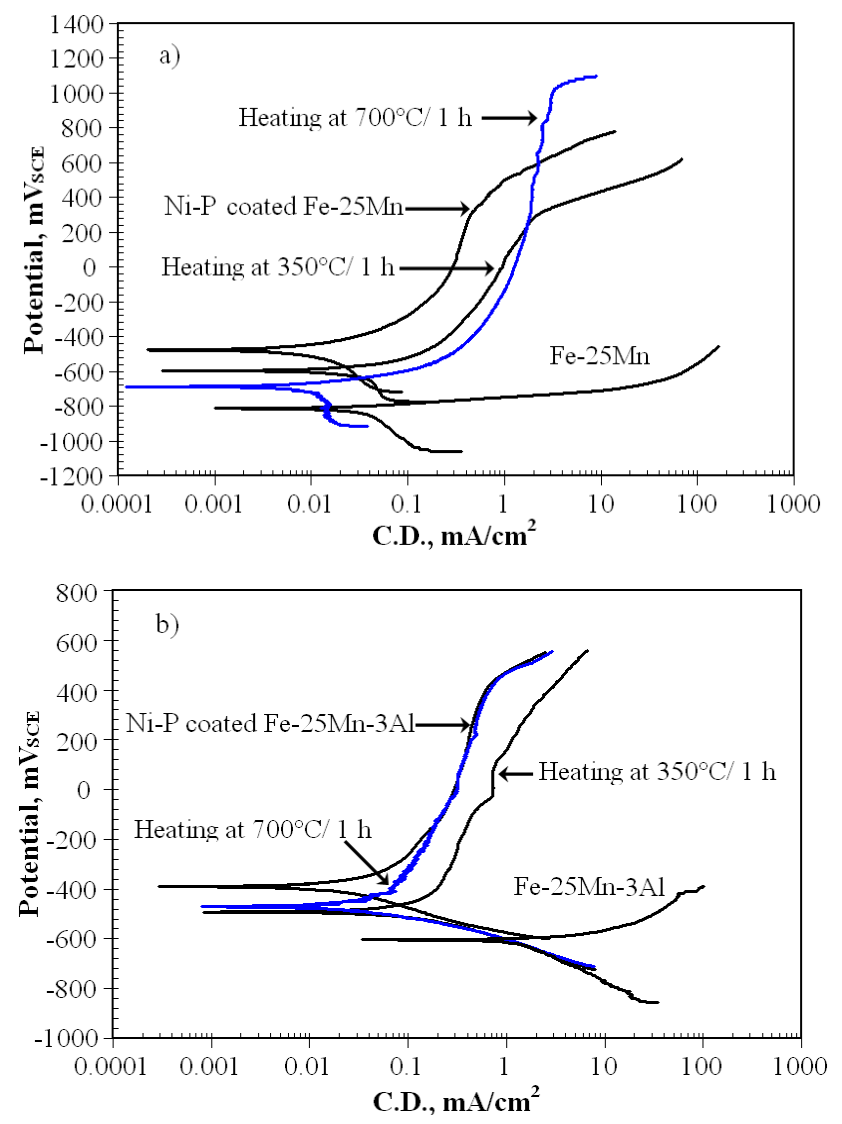

Fig. (4). Potentiodynamic polarization curves of electroless Ni-P coated steels with different heat treatments (a) Fe-25Mn in $3.5 \%$ $\mathrm{NaCl}$, (b) Fe-25Mn-3Al in $0.1 \mathrm{M} \mathrm{H}_{2} \mathrm{SO}_{4}$.

It can be seen in Fig. (4a) that in $3.5 \% \mathrm{NaCl}$ the type of corrosion attack on the Fe-25Mn steel is general corrosion with a high current density $\left(\mathrm{I}_{\text {corr }}=28 \mu \mathrm{A} / \mathrm{cm}^{2}\right)$. Moreover, the corrosion potential $\left(\mathrm{E}_{\text {corr }}=-816 \mathrm{mV}\right)$, a reliable parameter that indicates the tendency of the system to corrode, is more negative.

Table 2. Corrosion Current Density $I_{\text {corr }}$ and Potential $E_{\text {corr }}$ of the Ni-P Coatings on the TWIP Steels in $3.5 \%$ $\mathrm{NaCl}$ and $0.1 \mathrm{M} \mathrm{H}_{2} \mathrm{SO}_{4}$ Solutions

\begin{tabular}{|c|c|c|c|c|}
\hline \multirow{2}{*}{$\begin{array}{c}\text { Steel/Coating } \\
\text { Treatment }\end{array}$} & \multicolumn{2}{|c|}{$\mathbf{F e - 2 5 M n / 3 . 5 \% ~ N a C l}$} & \multicolumn{2}{c|}{$\mathbf{F e - 2 5 M n - 3 A l} / \mathbf{H}_{2} \mathbf{S O}_{4}$} \\
\cline { 2 - 5 } & $\begin{array}{c}\mathbf{I}_{\text {corr }} \\
\left(\mu \mathbf{A} / \mathbf{c m}^{2}\right)\end{array}$ & $\begin{array}{c}\mathbf{E}_{\text {corr }} \\
\left(\mathbf{m V}_{\text {SCE }}\right)\end{array}$ & $\begin{array}{c}\mathbf{I}_{\text {corr }} \\
\left(\mu \mathbf{A} / \mathbf{c m}^{2}\right)\end{array}$ & $\begin{array}{c}\mathbf{E}_{\text {corr }} \\
\left(\mathbf{m V}_{\text {SCE }}\right.\end{array}$ \\
\hline \hline Uncoated & 28 & -816 & 3217 & -608 \\
\hline As-plated & 6 & -477 & 20 & -390 \\
\hline $350^{\circ} \mathrm{C}$ for $1 \mathrm{~h}$ & 19 & -597 & 81 & -490 \\
\hline $700^{\circ} \mathrm{C}$ for $1 \mathrm{~h}$ & 9 & -689 & 33 & -469 \\
\hline
\end{tabular}

The data in Table 2 indicates that the Ni-P coatings improve the corrosion resistance, decrease $\mathrm{I}_{\text {corr }}$ by a factor of 4 , but the benefit decreases with the post-heat treatment. The as-plated Ni-P coating on Fe-25Mn exhibits the highest corrosion resistance, with lower $\mathrm{I}_{\text {corr }}=6 \mu \mathrm{A} / \mathrm{cm}^{2}$ and nobler $\mathrm{E}_{\text {corr }}=-477 \mathrm{mV}$ than the annealed coatings have. Raicheff and Zaprianova [21] suggested that the good corrosion resistance of amorphous electroless $\mathrm{Ni}-\mathrm{P}$ coating is due to their homogeneous structure and the absence of grain boundaries, dislocations, kink sites and other surface defects. Furthermore, the glassy film passivates the surface. When the Ni-P coating on $\mathrm{Fe}-25 \mathrm{Mn}$ is annealed at $350^{\circ} \mathrm{C}$, the corrosion resistance decreases, seen as an increased corrosion current, $\mathrm{I}_{\text {corr }}=19 \mu \mathrm{A} / \mathrm{cm}^{2}$. This can be attributed to the formation of $\mathrm{Ni}_{3} \mathrm{P}$ particles at such temperatures, which in turn reduces the $\mathrm{P}$ content of the remaining material. It is suggested that $\mathrm{P}$ is responsible for the formation of an adsorbed film of hypophosphite, which blocks the water molecules from interacting with $\mathrm{Ni}$, thus inhibiting the oxidation of $\mathrm{Ni}$ [22]. Further, the presence of $\mathrm{Ni}_{3} \mathrm{P}$ particles creates active/passive corrosion cells, thus contributing detrimentally to the corrosion resistance of the coating.

The corrosion performance of the Ni-P coating on Fe$25 \mathrm{Mn}$ annealed at $700^{\circ} \mathrm{C}$ is different. Even though this coating shows a slightly higher corrosion current density $\left(\mathrm{I}_{\text {corr }}=9 \mu \mathrm{A} / \mathrm{cm}^{2}\right)$ than the as-plated steel. As shown in Fig. (4a), it presents two states, a stable passivation regime and a transpassivation at a high positive potential $(+1020 \mathrm{mV})$. This can be attributed to the formation of thin $\mathrm{MnO}$ layer, observed by GD-OES and SEM-EDX measurements, as an additional layer that enhances the passivation in the $3.5 \%$ $\mathrm{NaCl}$ solution. This $\mathrm{MnO}$ layer acts as a protective layer preventing the oxygen diffusion onto the coating surface during corrosion reactions.

Table 3. EDX Elemental Analysis (in wt.\%) of Regions in Fig. (5)

\begin{tabular}{|c|c|c|c|c|c|c|}
\hline Site & $\mathbf{S i}$ & $\mathbf{O}$ & $\mathbf{F e}$ & Mn & $\mathbf{P}$ & $\mathbf{N i}$ \\
\hline \multicolumn{7}{|c|}{ Fig. (5a): surface layer after annealing at $350^{\circ} \mathrm{C}$} \\
\hline 1 & & & & & 3.30 & 96.70 \\
\hline 2 & 0.46 & & & & 5.75 & 93.79 \\
\hline 3 & & & & & 12.56 & 87.44 \\
\hline \multicolumn{7}{|c|}{ Fig. (5b): surface layer after annealing at $700^{\circ} \mathrm{C}$} \\
\hline 1 & & 20.11 & & 26.73 & 11.67 & 41.49 \\
\hline 2 & & 14.31 & & 9.45 & 12.39 & 63.85 \\
\hline \multicolumn{7}{|c|}{ Fig. $(5 d)$ : cross-section after annealing at $700^{\circ} \mathrm{C}$} \\
\hline 1 & & & 1.52 & 3.25 & 5.32 & 89.91 \\
\hline 2 & & & 0.62 & 1.63 & 6.09 & 91.66 \\
\hline 3 & 0.39 & & 66.81 & 20.38 & & 12.42 \\
\hline 4 & 0.49 & & 72.70 & 26.81 & & \\
\hline \multicolumn{7}{|c|}{ Fig. (5e): surface layer after annealing at $700^{\circ} \mathrm{C}$} \\
\hline 1 & & 27.99 & 0.92 & 56.26 & 9.77 & 5.06 \\
\hline 2 & & 21.71 & & 33.49 & 11.60 & 33.20 \\
\hline
\end{tabular}

The polarization curves of the $\mathrm{Fe}-25 \mathrm{Mn}-3 \mathrm{Al}$ steel without the coating and after the plating in $0.1 \mathrm{M} \mathrm{H}_{2} \mathrm{SO}_{4}$ are plotted in Fig. (4b). As seen the corrosion rate of the uncoated steel is very high with $\mathrm{I}_{\text {corr }}=3217 \mu \mathrm{A} / \mathrm{cm}^{2}$. The Ni$P$ coating reduces $I_{\text {corr }}$ very significantly, by a factor of 40 (Table 1). The as-plated Ni-P coating exhibits the highest 

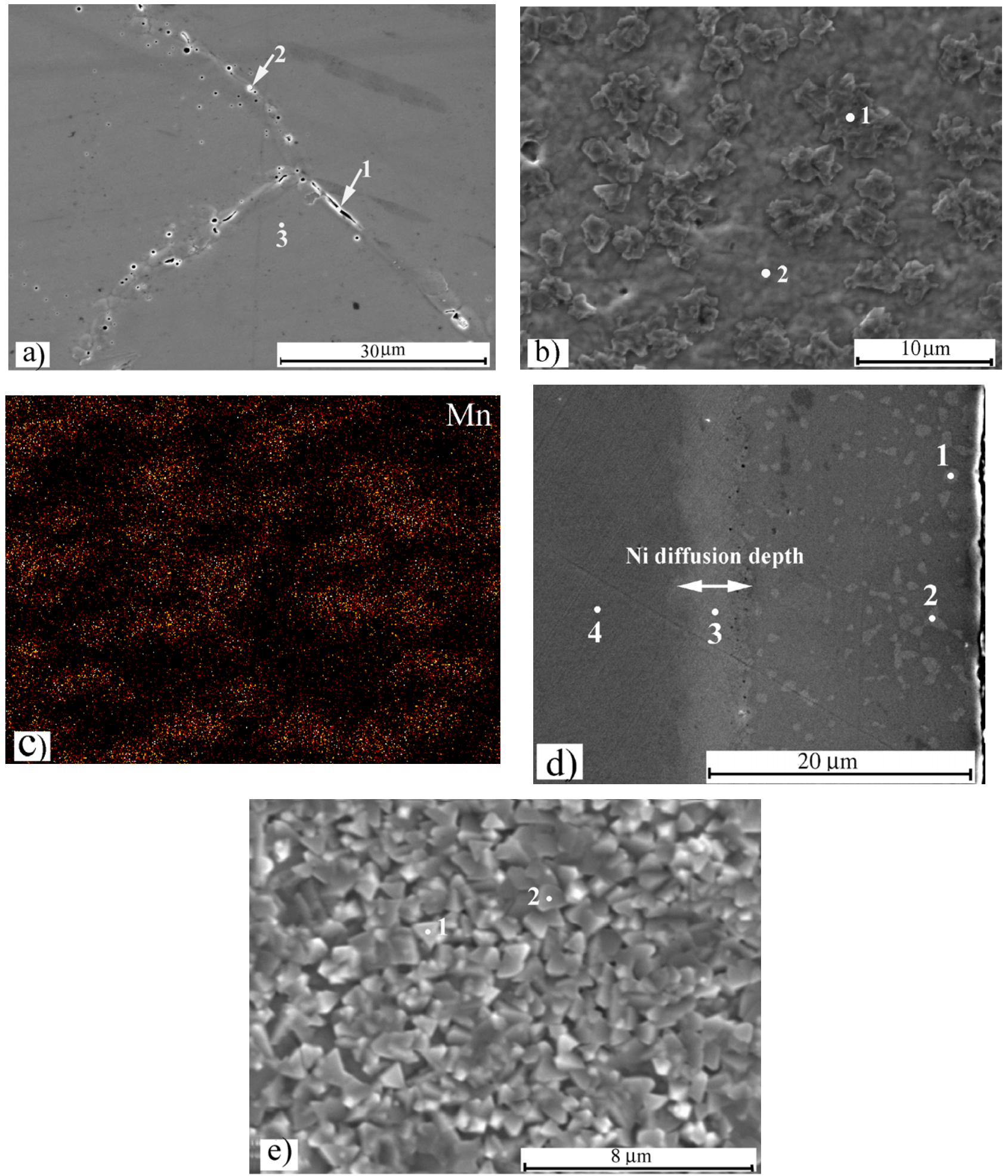

Fig. (5). SEM images of the EN-P coatings on two TWIP-steels, from (a) to (c) Fe-25Mn and (d) Fe-25Mn-3Al: (a) surface layer after annealing at $350^{\circ} \mathrm{C}$, (b) surface layer after annealing at $700^{\circ} \mathrm{C}$, (c) EDX-Mn distribution map of Fig. (5b), (d) cross-section after annealing at $700^{\circ} \mathrm{C},(\mathbf{e})$ surface layer after annealing at $700^{\circ} \mathrm{C}$.

corrosion resistance with $\mathrm{I}_{\text {corr }}=20 \mu \mathrm{A} / \mathrm{cm}^{2}$ and noblest $E_{\text {corr }}=-390 \mathrm{mV}$. However, the corrosion performance of the $\mathrm{Ni}-\mathrm{P}$ coating in $\mathrm{H}_{2} \mathrm{SO}_{4}$ annealed at $700^{\circ} \mathrm{C}$ was different from that in chloride solution. It did not show any passivation, but high $\mathrm{I}_{\text {corr }}=33 \mu \mathrm{A} / \mathrm{cm}^{2}$. It is well known that the lowest Mn oxide, $\mathrm{MnO}$, is entirely a basic oxide and reacts with aqueous acids and gives rise to the aqueous $\mathrm{Mn}^{+2}$ cations with hydrogen evolution [20], and consequently, the corrosion rate of such a layer is high.

The electrochemical reactions are surface reactions, and therefore it is important to examine the surface layer of Ni-P deposits after the heat treatments using SEM. It can be seen 
in Fig. (5a), the surface of the EN-P coating annealed at $350^{\circ} \mathrm{C}$ contains coarse particles of $\mathrm{Ni}_{3} \mathrm{P}$; see Table 3 and three sites of the EDX analysis in Fig. (5a), which act as cathodic regions on the coating. The grey to green basic $\mathrm{MnO}$ forms on the surface of the coating within heating at $700^{\circ} \mathrm{C}$ as a result from Mn diffusion into the surface coating, as shown in Fig. (5b). The EDX- Mn-distribution map of the area in Fig. (5b) is shown in Fig. (5c). Further, the chemical concentration in two sites of Fig. (5b) are listed in Table $\mathbf{3}$. The cross-section of the EN-P coating annealed at $700^{\circ} \mathrm{C}$, Fig. (5d), shows the formation of particles of $\mathrm{Mn}, \mathrm{Ni}$ and $\mathrm{P}$, as result of the direct reaction between the diffused $\mathrm{Mn}, \mathrm{Ni}$ and $\mathrm{P}$ in the coating [22]. The diffusion depth of $\mathrm{Ni}$ into the $\mathrm{Fe}-25 \mathrm{Mn}$ steel can be detected and is shown by an arrow in Fig. (5d). Compositions at four locations are listed in Table 3. The MnO layer, evident from the compositions in Table $\mathbf{3}$, is more dense and compact on the Fe-25Mn-3Al steel, as shown in Fig. (5e). This enhances the stability of the layer in a corrosion media.

\section{SUMMARY}

The electroless Ni-P coatings were deposited to enhance the corrosion resistance of two high-Mn TWIP steels. The potentiodynamic polarization tests in $3.5 \% \mathrm{NaCl}$ and $0.1 \mathrm{M}$ $\mathrm{H}_{2} \mathrm{SO}_{4}$ showed that Ni-P coating improved significantly the corrosion resistance in both media. The post-heat treatment for $1 \mathrm{~h}$ at $350^{\circ} \mathrm{C}$ or $700^{\circ} \mathrm{C}$ crystallized the amorphous structure of the coating and resulted in formation of $\mathrm{Ni}_{3} \mathrm{P}$ precipitates that increased significantly the hardness but resulted in decreasing corrosion resistance, ductility and adhesion strength. Precipitation of $\mathrm{Ni}_{3} \mathrm{P}$ particles and crystallization were presumably the factors reducing the corrosion resistance of the heat-treated coatings. At $700^{\circ} \mathrm{C}$, the annealing led to the formation of $\mathrm{MnO}$ as an additional layer on the coating surface, and this layer provided a stable passivation regime in the chloride solution.

\section{ACKNOWLEDGEMENTS}

The authors would like to thank Y. Shindo, ArcelorMittal Steel, Research \& Development Center 3001 E. Columbus Drive, East Chicago, IN 46312, USA, for his assistance in carrying out the elemental analysis by the GD-OES.

\section{REFERENCES}

[1] Sato K, Tanaka K, Inoue Y. Determination of the $\alpha / \gamma$ equilibrium in the iron rich portion of the Fe-Mn-Al system. ISIJ Int 1989; 29 : 788-92.

[2] Krüger L, Meyer LW, Brüx U, Frommeyer G, Grässel O. Stressdeformation behaviour of high manganese (Al, Si) TRIP and TWIP steels. J Phys IV 2003; 110: 189-94.
[3] Frommeyer G, Brüx U, Neumann P. Supra-ductile and highstrength manganese-TRIP/TWIP steels for high energy absorption purposes. ISIJ Int 2003; 43: 438-46.

[4] Grässel O, Krüger L, Frommeyer G, Meyer LW. High strength Fe$\mathrm{Mn}-(\mathrm{Al}, \mathrm{Si}) \quad \mathrm{TRIP} / \mathrm{TWIP}$ steels developments-propertiesapplication. Int J Plast 2000; 16: 1391-409.

[5] Raynor GV, Rivlin VG. Phase equilibria in iron ternary alloys. Bath Press: England 1988.

[6] Allain S, Chateau JP, Bouaziz O, Migot S, Guelton N. Correlations between the calculated stacking fault energy and the plasticity mechanisms in Fe-Mn-C alloys. Mater Sci Eng A 2004; 387-389: $158-62$.

[7] Zhang YS, Zhu XM. Electrochemical polarization and passive film analysis of austenitic $\mathrm{Fe}-\mathrm{Mn}-\mathrm{Al}$ steels in aqueous solutions. Corr Sci 1999; 41: 1817-33.

[8] Zhu XM, Zhang YS. Electrochemical polarisation and passive film of austenitic Fe-Mn-Cr-Al alloy in aqueous solution. Br Corr J 1997; 32: 127-31.

[9] Hamada AS, Karjalainen LP. Nitric acid resistance of new type FeMn-Al stainless steels. Canad Metal Quart 2006; 45: 41-48.

[10] Hamada AS, Karjalainen LP, Somani MC, Ramadan R. Deformation mechanisms in High-Al bearing High-Mn TWIP steels in hot compression and in tension at low temperatures. Mater Sci Forum 2007; 550: 217-22.

[11] El-Mallah AT, El-Ibiary NS, Gad, MR, Morsy MS. Corrosion resistance of electroless nickel in food acid environments. Met Finish 1988; 86: 59-61.

[12] Salvago G, Fumagalli G, Brunella F. Corrosion behaviour of electroless Ni-P coatings in chloride-containing environments. Surf Coat Technol 1989; 37: 449-60.

[13] Krishnan KH, John S, Srinivasan KN, Praveen J, Ganesan M, Kavimani PM. An overall aspect of electroless Ni-P depositions. Metal Mater Trans A 2006; 37A: 1917-26.

[14] Hamada AS, Karjalainen LP, Somani MC. The influence of aluminum on hot deformation behavior and tensile properties of high-Mn TWIP steels. Mater Sci Eng A 2007 ; 467: 114-24.

[15] Ashassi-Sorkhabi H, Rafizadeh SH. Effect of coating time and heat treatment on structures and corrosion characteristics of electroless Ni-P alloy deposits. Surf Coat Technol 2004; 176: 318-26

[16] Hu Y, Wang T, Meng J, Rao Q. Structure and phase transformation behaviour of electroless Ni-W-P on aluminium alloy. Surf Coat Technol 2006; 201: 988-92.

[17] Tsai Y, Wu F, Chen Y, Peng P, Duh J, Tsai S. Thermal stability and mechanical properties of Ni-W-P electroless deposits. Surf Coat Technol 2001; 146-147: 502-07.

[18] Peteline S, Mehrer H, Huang ML, Chang YA. Self-diffusion in nickel-manganese alloys. Mater Sci Forum 2005; 237-240: 352-57.

[19] Frommeyer G, Brüx U. Microstructures and mechanical properties of high-strength Fe-Mn-Al-C light-weight TRIPLEX steels. Steel Res Int 2006; 77: 627-33.

[20] Greenwood NN, Earnshaw A. Chemistry of elements. Butterworth Heinemann: UK 1997.

[21] Raicheff R, Zaprianova V. Effect of crystallization on the electrochemical corrosion behavior of some nickel-based amorphous alloys. J Mater Sci Lett 2000; 19: 3-5.

[22] Sankara Narayanan TSN, Baskaran I, Krishnaveni K, Parthiban S. Deposition of electroless Ni-P graded coatings and evaluation of their corrosion resistance. Surf Coat Technol 2006; 200: 3438-45. 